\title{
ORIGINALIST THEORY AND PRECEDENT: A PUBLIC MEANING APPROACH ${ }^{1}$
}

\author{
SETTLED VERSUS RIGHT: A THEORY OF \\ PRECEDENT. By Randy J. Kozel. ${ }^{2}$ Cambridge University \\ Press. 2017. PP. $\mathrm{x}+180 . \$ 99.99$ (hardcover), $\$ 34.99$ (paper).
}

\author{
Lawrence B. Solum ${ }^{3}$
}

\section{INTRODUCTION: ORIGINALISM AND PRECEDENT, AGAIN?}

Much ink has already been spilled on the relationship of constitutional originalism to precedent (or, more specifically, the doctrine of stare decisis). ${ }^{4}$ The debate includes contributions from

1. Copyright 2018 by the author. Permission is hereby granted to make copies including copies in electronic form for educational or scholarly purposes.

2. Professor of Law, Notre Dame Law School.

3. Carmack Waterhouse Professor of Law, Georgetown University Law Center.

4. The theoretical position that is outlined in this Part provides the gist of ideas contained in several articles. See Lawrence B. Solum, Triangulating Public Meaning: Corpus Linguistics, Immersion, and the Constitutional Record, BYU L. REV. (forthcoming 2018); Lawrence B. Solum, Originalist Methodology, 84 U. CHI. L. REV. 269 (2017); Lawrence B. Solum, The Fixation Thesis: The Role of Historical Fact in Original Meaning, 91 Notre Dame L. ReV. 1 (2015); Lawrence B. Solum, Intellectual History as Constitutional Theory, 101 VA. L. REV. 1111 (2015); Lawrence B. Solum, Communicative Content and Legal Content, 89 Notre Dame L. Rev. 479 (2013); Lawrence B. Solum, Originalism and Constitutional Construction, 82 FORDHAM L. REV. 453 (2013); Lawrence B. Solum, What Is Originalism?, in THE ChALlenge OF ORIGINALISM: EsSAYS IN CONSTITUTIONAL THEORY (Grant Huscroft \& Bradley W. Miller eds., 2011); Lawrence B. Solum, The Interpretation-Construction Distinction, 27 CONST. COMMENT. 95 (2010); Lawrence B. Solum, Incorporation and Originalist Theory, 18 J. CONTEMP. LEGAL ISSUES 409, 440 (2009); Lawrence B. Solum, District of Columbia v. Heller and Originalism, 103 NW. U. L. REV. 923 (2009). In addition to the published and forthcoming articles, works in progress include Lawrence B. Solum, The Public Meaning Thesis (Aug. 20, 2015) (unpublished manuscript) (on file with author); Lawrence B. Solum, The Constraint Principle: Original Meaning and Constitutional Practice (Apr. 11, 2018) (unpublished manuscript), https://papers.ssrn.com/sol3/papers.cfm?abstract_id=2940215. 
Randy Barnett, ${ }^{5}$ Steven Calabresi,${ }^{6}$ Kurt Lash, ${ }^{7}$ Gary Lawson, ${ }^{8}$ John McGinnis with Michael Rappaport, ${ }^{9}$ Michael Paulsen, ${ }^{10}$ and Lee Strang, ${ }^{11}$ not to mention Justice Antonin Scalia ${ }^{12}$-all representing originalism in some form. Living constitutionalism has also been represented both implicitly and explicitly, with important contributions from Phillip Bobbitt, ${ }^{13}$ Ronald Dworkin, ${ }^{14}$ Michael Gerhardt, ${ }^{15}$ Randy Kozel, ${ }^{16}$ and David Strauss. ${ }^{17}$ Some writers are more difficult to classify; Akhil Amar comes to mind. ${ }^{18}$ And there are many other contributions to the debate. ${ }^{19}$ Opinions range from the view that precedent should

5. Randy E. Barnett, Trumping Precedent with Original Meaning: Not as Radical as It Sounds, 22 CONST. COMMENT. 257 (2005).

6. Steven G. Calabresi, The Tradition of the Written Constitution: Text, Precedent, and Burke, 57 ALA. L. REV. 635, 637 (2006).

7. Kurt T. Lash, Originalism, Popular Sovereignty, and Reverse Stare Decisis, 93 VA. L. REV. 1437, 1480-81 (2007).

8. Gary Lawson, The Constitutional Case Against Precedent, 17 HARV. J.L. \& PUB. POL'Y 23 (1994); Gary Lawson, Mostly Unconstitutional: The Case Against Precedent Revisited, 5 AVE MARIA L. REV. 1, 1 (2007). For critiques of Lawson, see Akhil Reed Amar, On Lawson on Precedent, 17 HARV. J.L. \& PUB. POL'Y 39 (1994); Charles Fried, Reply to Lawson, 17 HARV. J.L. \& PUB. POL'Y 35 (1994); Frederick Schauer, Precedent and the Necessary Externality of Constitutional Norms, 17 HARV. J.L. \& PUB. POL'Y 45 (1994).

9. JOHN O. MCGINNIS \& MICHAEL B. RAPPAPORT, ORIGINALISM AND THE GOOD CONSTITUTION 169 (2013).

10. Michael Stokes Paulsen, The Intrinsically Corrupting Influence of Precedent, 22 Const. COMment. 289, 291 (2005); Michael Stokes Paulsen, The Irrepressible Myth of Marbury, 101 MicH. L. REV. 2706, 2731-34 (2003); Michael Stokes Paulsen, Abrogating Stare Decisis by Statute: May Congress Remove the Precedential Effect of Roe and Casey?, 109 YALE L.J. 1535, 1537 n.1 (2000).

11. Lee J. Strang, An Originalist Theory of Precedent: The Privileged Place of Originalist Precedent, 2010 BYU L. REV. 1729.

12. ANTONIN SCALIA, A MATTER OF INTERPRETATION: FEDERAL COURTS AND THE LAW 138-40 (Amy Gutmann ed., 1997).

13. PHILIP BOBBITT, CONSTITUTIONAL INTERPRETATION 12-13 (1991).

14. The most important text in Dworkin's extensive body of work is RONALD DWORKIN, LAW'S EMPIRE (1986); see also RONALD DWORKIN, FREEDOM'S LAW: THE Moral Reading of the American CONSTITUTiOn (1996); RONALD Dworkin, A MATTER OF PRINCIPLE (1985).

15. Michael J. Gerhardt, Super Precedent, 90 MinN. L. REV. 1204 (2006).

16. RANDY J. Kozel, SETTLEd Versus Right: A THEORY OF PRECEDENT (2017); Randy J. Kozel, Original Meaning and the Precedent Fallback, 68 VAND. L. REV. 105, 105 (2015).

17. David A. Strauss, The Living Constitution (2010).

18. Akhil Reed Amar, Foreword: The Document and the Doctrine, 114 HARV. L. REV. 26, 78-89 (2000).

19. See, e.g., Amy Coney Barrett, Stare Decisis and Due Process, 74 U. Colo. L. REV. 1011 (2003); John Tuskey, Do as We Say and Not (Necessarily) as We Do: The Constitution, Federalism, and the Supreme Court's Exercise of Judicial Power, 34 CAP. U. L. REV. 153, 180-81 (2005). 
invariably prevail over the original public meaning of the constitutional text to the polar opposite view, that precedent must give way to original meaning in almost every case. ${ }^{20}$

Here is the roadmap. Part I provides a brief introduction to contemporary originalism. Part II describes the problem of precedent for originalism, emphasizing that the nature of the problem depends in part on our understanding of precedent. Part III offers some reflections on the question as to the constitutional status of the doctrine of horizontal stare decisis in the United States Supreme Court.

\section{A VERY BRIEF INTRODUCTION TO PUBLIC MEANING ORIGINALISM}

"Public Meaning Originalism" (PMO) is the version of originalist constitutional theory that holds that the content communicated by the constitutional text to the public at the time each provision was framed and ratified is binding on constitutional actors. Like almost all the other members of the originalist family of constitutional theories ${ }^{21}$ PMO includes two core ideas: (1) the Fixation Thesis (the meaning of each constitutional provision is fixed at the time the provision was framed and ratified), and (2) the Constraint Principle (constitutional practice should, at a minimum, be consistent with the original meaning of the constitutional text). ${ }^{22}$

PMO goes beyond the core by arguing that the best understanding of "original meaning" is the public meaning of the constitutional text at the time each provision was framed and ratified: this is the Public Meaning Thesis. ${ }^{23}$ The public meaning of the constitutional text is the communicative content, understood as the content communicated to the public by the text and the publicly available context of constitutional communication. Thus, the original meaning is a function of both (1) semantics and (2) contextual enrichment. The semantic

20. The range of opinions is surveyed in infra Part II.B.

21. Original law originalism may be an exception. See Stephen E. Sachs, Originalism Without Text, 127 YALE L.J. 156, 161 (2017) (arguing that the Fixation Thesis would not play a role in a possible world in which there was not constitutional text but not taking a position on the role the text played in the original law).

22. Phrases like "Public Meaning Originalism," "Fixation Thesis" and "Constraint Principle" are capitalized to indicate that they are proper names for the specific views as defined.

23. See Solum, The Public Meaning Thesis, supra note 4. 
meaning of the constitutional text is produced by the conventional semantic meanings of the words and phrases as combined by syntax (roughly, grammar and punctuation): this is sometimes called the "literal meaning" of the text. But "literal meaning" is not the same as the original public meaning of the text. For one thing, semantic ambiguities are usually resolved by context. For another, the full communicative content of the text includes what philosophers of language and linguistic theorists call "pragmatics": I will use the phrase "contextual enrichment" 24 to refer to the content generated by implicatures, implicitures, presuppositions, modulations, and free enrichments. ${ }^{25}$ Thus, the full communicative content communicated to the public by the constitutional text is contextually disambiguated and enriched semantic content.

Other members of the originalist family differ from PMO in their account of the nature of original meaning. For example, the most sophisticated contemporary version of intentionalism holds that the meaning of the constitutional text is determined by the communicative intentions of the authors. ${ }^{26}$ Similarly, original methods originalism holds that the meaning of the text is the meaning that the text would have been given at the time of framing and ratification if the original methods of constitutional interpretation had been applied. ${ }^{27}$ Original law originalism is different: it holds that the original law (and not the meaning of the text) continues to be binding, unless it is properly changed by procedures authorized by the original law itself. ${ }^{28}$

Many originalists also affirm the interpretation-construction distinction. ${ }^{29}$ For the purposes of this Article, "interpretation" is

24. In the philosophy of language, the preferred phrase is "pragmatic enrichment." François Recanati, Pragmatic Enrichment, in THE Routledge CoMPANION TO PhilOSOPHY OF LANGUAGE 67 (Gillian Russell \& Delia Graff Fara eds., 2012).

25. See Solum, Originalist Methodology, supra note 4; Solum, Triangulating Public Meaning, supra note 4.

26. See Larry Alexander, Simple-Minded Originalism, in THE CHALlEnge of ORIGINALISM (Grant Huscroft \& Bradley W. Miller eds., 2011). A different approach that does not specify a conception of "intention" is found in the work of Richard Kay. See, e.g.,

Richard S. Kay, Adherence to the Original Intentions in Constitutional Adjudication: Three Objections and Responses, 82 Nw. U. L. REV. 226 (1988).

27. See MCGINNIS \& RAPPAPORT, THE GOOD CONSTITUTION, supra note 9.

28. See William Baude, Is Originalism Our Law?, 115 COLUM. L. REv. 2349 (2015); Stephen E. Sachs, Originalism as a Theory of Legal Change, 38 HARV. J.L. \& PUB. POL'Y 817 (2015).

29. See Solum, The Interpretation-Construction Distinction, supra note 4. 
stipulated to be the activity that discovers the meaning (more precisely, communicative content ${ }^{30}$ ) of the constitutional text. "Construction" is stipulated to be the activity that determines the legal effect to be given that meaning. Legal effects include the decision of cases by courts, constitutional actions by officials and institutions and the announcement of legal norms in the form of constitutional doctrines-usually, but not always, contained in judicial opinions. Although this distinction might be described using a different vocabulary, the underlying conceptual distinction is fundamental and should be accepted by all constitutional theorists. The meaning of a text is one kind of thing; its application is a different kind of thing - no one should dispute this distinction. This distinction has a long history in American legal theory, beginning with Francis Lieber and crystallizing in the work of the great contracts scholar, Arthur Corbin. ${ }^{31}$

The interpretation-construction distinction interacts with the degree of constitutional underdeterminacy. ${ }^{32}$ For almost all originalists, if the constitutional text is determinate with respect to a particular issue or case, all of the important work is done at the interpretation stage (setting aside the role of precedent). Once we know the determinate meaning of the text, then the proper construction follows. But if the text is underdeterminate, allowing more than one possible outcome in a constitutional case, then constitutional construction will be required.

30. The communicative content of the constitutional text is best conceptualized as the set of concepts and propositions conveyed by the text-in the philosophical sense of "propositions" and "concepts." See Matthew McGrath \& Devin Frank, Propositions, in THE STANFORD ENCYClOPEDIA OF PhILOSOPHY (Edward N. Zalta ed., 2018), https://plato.stanford.edu/archives/spr2018/entries/propositions/.

31. See generally Greg Klass, Interpretation and Construction 1: Francis Lieber, NEW PRIV. L. (Nov. 19, 2015), http://blogs.harvard.edu/nplblog/2015/11/19/interpretation-andconstruction-1-francis-lieber-greg-klass/; Greg Klass, Interpretation and Construction 2: Samuel Williston, NEW PRIV. L. (Nov. 23, 2015), https://blogs.harvard.edu/nplblog/2015/11/23/interpretation-and-construction-2-samuelwilliston-greg-klass/; Greg Klass, Interpretation and Construction 3: Arthur Linton Corbin, NEW PRIV. L. (Nov. 25, 2015), http://blogs.harvard.edu/nplblog/2015/11/25/interpretationand-construction-3-arthur-linton-corbin-greg-klass/; see also Ralf Poscher, The Hermeneutical Character of Legal Construction, in LAW'S HERMENEUTICS: OTHER INVESTIGATIONS (Simone Glanert \& Fabien Girard eds., 2016), http://ssrn.com/abstract=2696486.

32. On the role of determinacy in originalist theory, see Heidi Kitrosser, Interpretive Modesty, 104 GEO. L.J. 459 (2016); see also Lawrence B. Solum, On the Indeterminacy Crisis: Critiquing Critical Dogma, 54 U. CHI. L. REV. 462 (1987). 
We can use the phrase "construction zone" 33 to refer to the set of issues with respect to which the original meaning of the constitutional text is underdeterminate. Similarly, the phrase "interpretation zone" ${ }^{34}$ can be used to designate the case where the crucial work is done by the communicative content of the constitutional text. The version of PMO developed in my work affirms the interpretation-construction distinction and assumes moderate constitutional underdeterminacy.

An originalist methodology describes the practices by which the original meaning of the constitutional text can be discovered. Ideally, an originalist methodology will provide a set of best practices that yield results that can be replicated and verified. In Triangulating Public Meaning: Corpus Linguistics, Immersion, and the Constitutional Record ${ }^{35}$ I have suggested that original public meaning can best be determined using a combination of three techniques: (1) the method of corpus linguistics, (2) the method of studying the constitutional record, and (3) the method of originalist immersion. Each of these three methods provides a check on the others, allowing for the triangulation of public meaning.

The debate about the proper relationship between originalism and precedent can be understood in two distinct ways: first, as a debate internal to originalist constitutional theory, and second, as an external critique of originalism. The internal debate is complicated by the theoretical differences among originalists. Likewise, the external critique is complexified by the many different versions of nonoriginalist constitutional theory. Of necessity, this Review simplifies, focusing on PMO as the representative form of originalism and relying on a generic form of nonoriginalist living constitutionalism to stand in for many distinct views.

\section{THE PROBLEM OF PRECEDENT FOR ORIGINALIST CONSTITUTIONAL THEORY}

With a brief introduction to PMO on the table, I now turn to a statement of the problem of precedent and originalism.

33. See Lawrence B. Solum, The Unity of Interpretation, 90 B.U. L. REV. 551, 572

34. Samuel P. Jordan \& Christopher K. Bader, State Power to Define Jurisdiction, 47

GA. L. REV. 1161, 1213 (2013) (using the phrase "interpretation zone").

35. See Solum, Triangulating Public Meaning, supra note 4. 


\section{A. Why IS PRECEDENT A PROBLEM FOR ORIGINALISM?}

Precedent is clearly a component of constitutional litigation as currently practiced. The opinions of the Justices and the briefs filed by parties are filled with citations to cases. But originalism seems (on the surface) to suggest that this is a mistake. If the public meaning of the constitutional text requires a certain outcome, then the Constraint Principle suggests that the citation of precedent is superfluous and adherence to authority that is contrary to original meaning is wrong. PMO seems to imply that current practice of precedent in constitutional cases is mistaken: a radical change is required. Some versions of living constitutionalism avoid this problem entirely; for example, common law constitutionalism relies on constraint by precedent as the primary alternative to constraint by the constitutional text.

Why is this implication of PMO a problem? One problem is very practical: the doctrine of stare decisis is pervasive, and it may be difficult to get judges and Justices to adhere to original meaning when it is inconsistent with precedent. But suppose that it is practically possible to comply with original meaning and overrule all the precedents that would stand in the way. There would still be a question as to whether it would be normatively desirable to do so. As we will see below, there is a range of views about the proper normative alignment of precedent and original meaning. ${ }^{36}$ The normative arguments favoring precedent over originalism are too numerous and complex to enumerate here. One especially difficult problem would occur during the transition to originalism: compliance with original meaning may require a wholesale revision in constitutional doctrine on a variety of topics and hence could introduce instability into the law. Another problem would arise if the precedents are normatively more attractive than the original meaning. The discussion that follows focuses on these "normative problems of precedent" for originalism.

\section{B. THE RANGE OF VIEWS}

Now consider the range of views about the proper relationship between precedent and original meaning. Some living constitutionalists take the position that precedent should always (or almost always) displace original meaning; we might call

36. See infra Part II.B. 
this the "living constitutionalist hard line." David Strauss represents this view; ${ }^{37}$ his version of common law constitutionalism makes precedent the alpha and omega of constitutional analysis. The hard line can be contrasted to what we call a "living constitutionalist soft line," which would allow the original meaning of the constitutional text to prevail over precedent in at least some cases. Constitutional pluralism allows for this possibility: if both precedent and text are methods or modalities of constitutional interpretation and construction, then there may be cases in which precedent must give way to the original meaning.

Some originalists, especially Gary Lawson ${ }^{38}$ and Michael Paulsen, ${ }^{39}$ advocate an "originalist hard line," taking the position that the original meaning must always (or almost always) prevail over precedent: because they believe that the constitution itself provides default rules that resolve what would otherwise be cases of underdetermination, their view (taken to its logical extreme) would seem to imply that precedent should play no role in constitutional adjudication. Other originalists are softliners. Famously, Justice Scalia, wrote, "stare decisis is not part of my originalist philosophy; it is a pragmatic exception to it." ${ }^{40}$ Randy Barnett allows for precedent to play a role in the construction zone. ${ }^{41}$ Lee Strang would allow for a stare decisis effect for originalist precedent. ${ }^{42}$

\section{THEORIES OF STARE DECISIS}

There is a large and complex literature on the theory of precedent and the doctrine of stare decisis, ${ }^{43}$ including Randy Kozel's important book, Settled Versus Right. The word "precedent" can refer to many things, but I will be discussing judicial precedent in the form of the doctrine of stare decisis for the remainder of this Article.

37. David A. Strauss, Foreword: Does the Constitution Mean What It Says?, 129 HARV. L. REV. 1, 57 (2015).

38. See supra note 8 for citations.

39. See supra note 10 for citations.

40. SCALIA, supra note 12, at 138-40.

41. Barnett, supra note 5.

42. Strang, supra note 11.

43. Larry Alexander, Constrained by Precedent, 63 S. CAL. L. REV. 1 (1989); Frederick Schauer, Precedent, 39 STAN. L. REV. 571 (1987). 
Vertical and horizontal stare decisis should be distinguished..$^{44}$ Vertical stare decisis requires lower courts to give binding effect to the holdings of higher courts to which they are subordinate, whereas horizontal stare decisis requires a court to give its own prior decisions something that is less than binding effect but more than merely persuasive effect.

Although I cannot marshal the evidence on this occasion, I believe that there are at least three distinct theories of stare decisis that are explicitly or implicitly operating in the courts in the United States. The first of these theories is what I will call the "ratio decidendi view." It maintains that the holding of a case is the rule that is logically entailed by the reasoning that was necessary to reach the outcome on the basis of the legally salient facts and the arguments of the parties. The second theory I call the "legally salient facts account." This view maintains that the holding of the case requires that the same outcome be reached if and only if all of the legally salient facts are identical. The third theory is the "predictive theory," which is the view that the holding of a case is the best prediction of the rule that the court would use to decide future cases: this theory gives special weight to "we hold that" statements, because such statements are especially good evidence of the court's likely future behavior. ${ }^{45}$

These three theories are radically different from one another. The predictive theory allows for very broad holdings that reach far beyond the facts of the particular case. The legally salient facts account results in very narrow holdings, because in almost all cases there are numerous facts that are legally salient: broad rules only emerge from a series of decisions. The ratio decidendi view can result in either broad or narrow holdings, depending on the reasoning used to reach the outcome and its interaction with the facts and arguments of the parties. My impression is that the current state of the doctrine of stare decisis is radically disordered. Many judges cannot even articulate their own theory of stare decisis, adopting an eclectic approach that uses different theories on different occasions. Worse, some judges may use more than one theory on a single occasion. Sadly, many in the legal academy

44. See Peter Wesley-Smith, Theories of Adjudication and the Status of Stare Decisis, in PRECEDENT IN LAW 81-82 (Laurence Goldstein ed., 1987).

45. See generally Lawrence B. Solum, Holdings, LEGAL THEORY LeXICON (last modified July 30, 2017), http://ssolum.typepad.com/legal_theory_lexicon/2003/10/legal_ theory_le_2.html. 
are equally confused, reflecting decades of neglect of this important topic.

\section{The EAsier Problem of Vertical Precedent}

What should originalists say about vertical precedent? For example, what should a United States District Court judge do when the holding of a Supreme Court case requires an outcome that differs from the outcome required by the original meaning? Although there is room for reasoned disagreement, the conventional wisdom is that this is an easy case: the lower court is bound by the decisions of the Supreme Court. Even if one believes that the Supreme Court itself should always follow the original meaning, there are very strong arguments that lower courts should not strike out on their own. If every judge were authorized to impose their own view of the original meaning of the constitutional text, the rule of law values of predictability, certainty, stability, publicity, and uniformity would be undermined. Given the reality that different judges may have different views about original meaning, there is even potential for a kind of judicial anarchy that could lead to substantial disorder. From an originalist perspective, there is a further question, whether vertical stare decisis is consistent with the public meaning of the constitutional text: some remarks on this topic are provided below. ${ }^{46}$

\section{E. The HARder Problem of Horizontal PreCEDENT}

What about the United States Supreme Court? Or a state court of last resort in cases arising under a state constitution? How should these courts deal with horizontal precedent when it conflicts with original meaning? This problem is only hard for those who accept originalism or adhere to a version of living constitutionalism that includes both original meaning and precedent as methods or modalities of constitutional interpretation and construction. For a common law constitutionalist, there is no problem at all: precedent or departures from precedent justified by common law methods always win.

Why might originalists go with precedent rather than original meaning? There are several possibilities, including the following:

46. See infra Part III. 
(1) the original meaning of the constitution itself requires adherence to precedent; (2) although original meaning should prevail over precedent as a matter of ideal theory, there are good and sufficient reasons to adhere to precedent as a matter of nonideal theory during a period of transition from living constitutionalism to originalism; (3) although original meaning is binding as a source of first order reasons, there are good and sufficient second-order reasons to utilize a system that incorporates the doctrine of stare decisis as the mechanism by which original meaning is determined. Part III of this Article will offer some observations about the first possibility - that original meaning requires adherence to precedent. The other three possibilities are explored in the remainder of this Part.

\section{F. PRECEDENT AND THE UNDERLYING JUSTIFICATIONS FOR ORIGINALISM}

Originalists differ with respect to the underlying justifications for originalism. To simplify, let us assume that there are two primary strands of justification: (1) the rule of law and (2) democratic legitimacy. What implications do these different justifications have for the role of precedent in an originalist jurisprudence? In the discussion that follows, I will argue that this role should be understood as transitional. In the discussion that follows, I will discuss two justifications for the Constraint Principle: the first focuses on the rule of law and the second is based on the idea of democratic legitimacy. ${ }^{47}$ Each justification for constraint has implications for the role of precedent in the transition to originalism.

The full case for originalism on the basis of the rule of law is complex and multidimensional, ${ }^{48}$ but one version of the argument focuses on the rule of law values of predictability, certainty, stability, publicity, and uniformity. Consider the following thought experiment:

Originalist Big Bang Thought Experiment: The appointment of nine originalist judges within a few years creates a system of constitutional adjudication in which the Supreme Court decides each and every constitutional issue solely on the basis

47. See Solum, The Constraint Principle, supra note 4

48. Id. (describing three distinct rule-of-law justifications for the Constraint Principle, including (1) an argument from the rule of law values, (2) an argument from judicial tyranny, and (3) an argument from politicization of the judiciary). 
of the Court's best current judgment about the original meaning of the constitutional text. This results in an originalist big bang. Over the course of a few terms, the Supreme Court (1) invalidates all independent regulatory agencies based on the original meaning of executive, legislative, and judicial power, (2) strikes down half the provisions of the United States Code as exceeding Congress's enumerated powers, (3) prohibits plea bargaining and requires jury trials in all criminal cases, (4) eliminates substantive due process, and (5) restores the original meaning of the Privileges and Immunities Clause. As a result of the big bang, federal law as a whole becomes unpredictable, inconsistent, and uncertain. ${ }^{49}$

In the hypothetical world of the thought experiment, an originalist big bang would be inconsistent with the rule of law justification for originalism.

For this reason, even a Supreme Court with nine originalist Justices might adhere to precedent during a transitional period. Indeed, this idea of a gradual transition to originalism could be built into originalism itself: for example, I have articulated a version of the Constraint Principle that requires consistency with originalism "in due course" and not immediately. ${ }^{50}$ The length of the transition period would depend on the extensiveness of the changes required by originalism and judgments about the rapidity with which they could be effected without damage to the rule of law. And this might depend on reactions from the political system: for example, an initial decision suggesting the unconstitutionality of one independent regulatory agency might create political conditions that would enable a constitutional amendment that squared such agencies (with proper safeguards) with the rule of law.

Likewise, the democratic legitimacy rationale for originalism might justify gradual implementation of the Constraint Principle. ${ }^{51}$ Some precedents might actually be consistent with

49. I am not taking the position that originalism would require all of the five outcomes described in text. This is a thought experiment, not an analysis of the original meaning of the constitutional text.

50. This is the position I take in Solum, The Constraint Principle, supra note 4 (manuscript at 21) (stating the Constraint Principle with the following qualifications: "If [the requirements of constraint as consistency] are not satisfied, then constitutional practice should be brought into compliance with constraint over time, giving due regard to the effects of constitutional change on the rule of law.").

51. In The Constraint Principle, I argue that there are three legitimacy-based justifications for constraint: (1) democratic legitimacy, (2) transparency, and (3) legitimate judicial role. See Solum, The Constraint Principle, supra note 4. 
democratic legitimacy: for example, nonoriginalist precedents in the voting rights area might be consistent with the underlying democratic legitimacy arguments for originalism. In other cases, clear and convincing evidence might indicate wide and deep support for precedents that are inconsistent with original meaning. In such cases, the value of democratic legitimacy might itself support a gradual transition to originalism, such that democratic processes could produce constitutional amendments that would bring the original meaning of the constitutional text into line with the results preferred by democratic consensus.

Randy Kozel has a different account of the relationship between the underlying justifications for originalism and precedent. Kozel maintains that forms of originalism are differentiated by their underlying justifications. Thus, "consequentialist originalism" is distinct from "popular sovereignty" originalism. Kozel then argues that the normative justifications for originalism directly bear on the question whether precedent is consistent with originalism (pp. 65-66). This move confuses first-order and second-order reasons. In the constitutional context, a first-order reason is the reason given for resolution of a constitutional case or issue, whereas a secondorder reason determines which first-order reasons should be brought to bear.

The whole point of originalism is to provide second-order reasons that make a certain kind of first-order reason mandatory. For PMO, the first-order reasons provided by the original public meaning of the constitutional text override other first-order reasons: this is the point of the Constraint Principle. Of course, the Constraint Principle must itself be justified in some way: the justifications for constraint are second-order reasons. For example, I have argued that the Constraint Principle is justified by two clusters of arguments, one based on the rule of law and the other grounded in the idea of democratic legitimacy. ${ }^{52}$

Kozel's argument implicitly assumes that the second-order reasons that justify a given form of originalism can then be applied directly to questions of constitutional interpretation. In other words, Kozel assumes that the second-order reasons that justify originalism provide first-order reasons to ignore originalism itself. This is a mistake, even if some originalists have made it: the whole

52. See Solum, The Constraint Principle, supra note 4 
point of a second-order reason is to specify what first-order reasons are required or permitted. For originalists, the idea that originalism is a method for "[d]eterming how costly it would be to uphold a precedent" shows a fundamental misunderstanding of originalism itself. Violations of the Constraint Principle are not a cost to be weighed in an all-things-considered judgment about what is the right thing to do: the balancing approach to constitutional practice is a form of nonoriginalist living constitutionalism.

Many of Kozel's arguments work, if they are limited to a period of transition from living constitutionalism to full implementation of originalism. But the same underlying justifications that support a transitional period would have different implications in the long run. The rule of law and democratic legitimacy support the Constraint Principle, which requires consistency with the constitutional text. Once the transition to originalism is complete, the use of precedent ought to be brought into line with the original meaning of the constitutional text.

\section{G. PRECEDENT AND NONIDEAL THEORY}

When originalism is presented as an ideal theory, ${ }^{53}$ many thorny problems are "swept under the rug." We simply assume a world in which originalism has already been adopted and in which all of the relevant constitutional actors both affirm originalism as the correct theory and are motivated to conform their actions to the Constraint Principle. In the actual world, originalism has not been adopted, many constitutional actors reject originalism, and even actors who affirm originalism in principle may not be motivated to comply with the Constraint Principle in some circumstances. Originalism is hotly debated, and it seems likely that many executive officials, members of Congress, judges, and Justices reject originalism.

Political and judicial originalism aim at the realization of originalism in both the long run and the short term. This means that many questions of tactics and strategy are on the table, especially in the early days of a transition to originalism. Originalist judges on a collegial court may need to write

53. For explication of the distinction between ideal and nonideal theories, see Lawrence B. Solum, Constitutional Possibilities, 83 IND. L.J. 307 (2008). 
nonoriginalist opinions as part of the give and take required to get judicial business done - and even to limit the number of occasions upon which they write extensive originalist concurrences and dissents. An originalist judge might make the tactical decision that a precedent-based decision that moves the law towards original meaning is better than a dissent or concurrence accompanying a decision that moves the law in the opposite direction.

Originalist senators might vote to confirm nonoriginalist judges as a matter of political compromise or accommodation to the fact that the judiciary must continue to function. Under actual political conditions, judges who are committed to precedent may be preferable to those who embrace judicial legislation unbound by law of any sort. For all these reasons and more, nonoriginalist precedent might be endorsed by political and judicial originalism (the practical versions of originalism for officials and judges) not as the first best option, but as an originalist second best. ${ }^{54}$

\section{H. PRECEDENT AND DisAgreEMENT AbOUt ORIGINAL MEANING}

In originalist heaven, there would be universal agreement about the original meaning of the constitutional text and every constitutional actor would comply with that meaning: precedent would have no role in constitutional practice. Every decision would be correct and adherence to precedent would be superfluous. But in the actual world, things are more complex. In the actual world, the original meaning of many constitutional provisions is uncertain. In the actual world, there is likely to be disagreement about original meaning. Some of that disagreement may result from good faith differences about the weighing of the evidence, but some may result from motivated reasoning or badfaith results-oriented manipulation of the evidence. Partially ideal theory should take these complications into account.

Given a world in which there is disagreement about original meaning, there are good reasons to create mechanisms of institutional settlement. The doctrine of stare decisis is such a mechanism. Vertical stare decisis centralizes institutional authority to determine original meaning in the Supreme Court. This centralization of authority would likely be superior to a

54. The idea of an originalist second-best is explored in Solum, Constitutional Possibilities, supra note 53. 
decentralized regime for reasons that have already been discussed. Decentralized authority over the law is unworkable, given substantial disagreement about legal content.

Horizontal stare decisis can play a similar role. The Justices of the Supreme Court may disagree about original meaning in good faith. Given the uncertainty about original meaning, horizontal stare decisis would facilitate the stability of law: mistakes about original meaning could be corrected, but deference to prior decisions would facilitate an orderly process. Without some such mechanism, the Court might change its mind about the correct interpretation of some constitutional provisions on a regular basis-as new evidence came to light or new arguments were made about the meaning of the evidence. Horizontal stare decisis on questions of interpretation might operate to preserve the status quo until clear and convincing evidence had produced a substantial consensus that there had been an error.

Notice that this justification for precedent only operates when the prior decision involved a good faith attempt to determine the original meaning of the constitutional text. Decisions that ignored original meaning or gave decisive weight to policy judgments about desirable outcomes would not be entitled to deference on this ground. Originalist precedents would be entitled to deference, but nonoriginalist precedents would only be followed for other reasons - such as those identified above. ${ }^{55}$

\section{PRECEDENT AND THE CONSTRUCTION ZONE}

The discussion so far has been about the relationship between precedent and interpretation, but from the perspective of PMO, there is a distinct question about the role of precedent in the construction zone. By definition, a case is in the construction zone if and only if the original meaning of the constitutional text is underdeterminate with respect to an outcome-affecting issue. Consider the simplest case, in which the text is vague or opentextured. Let us assume that the preferred method of constitutional construction requires the Court to precisify: for example, the Court needs to devise a rule to resolve the borderline cases between executive and legislative power. Once the Court has chosen a rule, the doctrine of horizontal stare

55. See supra Parts II.F, II.G. 
decisis could be applied without violating the Constraint Principle. Similar points could be made about what are called "implementing rules"-norms of constitutional law that implement original meaning.

For example, if the exclusionary rule were consistent with original meaning (a big "if") and if the exclusionary rule faithfully implemented the Fourth Amendment (another big "if"), then the doctrine of horizontal stare decisis would suggest that the cases establishing the rule should not be overturned without especially good reasons. Moreover, the rule of law might favor giving precedent in the construction zone "gravitational force" in order to produce constitutional norms that are coherent, consistent, and stable. Resolving issues about the precise role of precedent will be determined by a theory of constitutional construction, a topic that is addressed below. ${ }^{56}$

\section{PRELIMINARY THOUGHTS ABOUT A PUBLIC MEANING ORIGINALIST INQUIRY INTO THE CONSTITUTIONAL STATUS OF PRECEDENT}

From an originalist perspective, there is a further question: is stare decisis consistent with original meaning? The discussion that follows looks at this question from the perspective of PMO. Does the original public meaning of the constitutional text permit, forbid, or require a doctrine of stare decisis to be applied to questions of constitutional interpretation and construction? I provide a set of ideas about how a PMO inquiry should proceed but do not attempt to examine the evidence and reach conclusions.

The first step in the quest for original public meaning is an inquiry into the semantic meaning of the words and phrases. This requires identification of the relevant parts of the constitutional text and structure. The constitutional text makes no explicit reference to precedent or stare decisis. Nonetheless, there are clauses that might have implications for the constitutional status of precedent. The key phrases include "judicial power," "one Supreme Court," "inferior courts," and "the Supreme Law of the Land." Structurally, the division of authority between the supreme and the inferior courts and separation of powers between the "Judicial," "Executive," and "Legislative" branches

56. See infra text accompanying notes 59-61. 
may be relevant as well. The aim of PMO is to recover the communicative comments of the relevant clauses, as well as any additional content communicated by the constitutional structure. Practices, expectations, and goals may be relevant to this inquiry as evidence, but PMO does not take the position that these practices, expectations, and goals are binding at the interpretation stage. ${ }^{57}$

The best approach to recovering the original semantic meaning of the words and phrases would utilize corpus linguistics, but as of this writing the most useful data set, COFEA (the Corpus of Founding Era American English) is still in beta testing. ${ }^{58}$ Corpus analysis provides primary evidence of patterns of usage, which are constitutive of semantic meaning. Period dictionaries provide secondary evidence, and they may be especially helpful in identifying the range of possible senses (semantic meanings) of the semantic units that comprise the constitutional text. Similar analysis of syntax, including grammar and punctuation, would be required as well. Immersion in the period by study of a wide variety of texts provides a second route to the recovery of the relevant semantics and syntax.

The second step involves attention to context, including the context provided by the whole constitutional text, the constitutional record, relevant historical events (e.g., the Revolutionary War and experience under the Articles of Confederation), and other salient facts. From the perspective of $\mathrm{PMO}$, the relevant context is the publicly accessible contextthose features of the whole context that would have been accessible to the "public"-understood as citizens who were competent speakers of American English at the relevant time. The investigation of context requires study of the constitutional record and the history of the period. Once again, immersion provides a second route for recovery of the context that would have been accessible to the public.

The goal of such inquiry is the recovery of the full communicative content of the constitutional text: what did the

57. The role of practices, expectations, and goals at the construction stage is a different matter. See, e.g., Randy E. Barnett \& Evan D. Bernick, The Letter and the Spirit: A Unified Theory of Originalism, GEO. L.J. (forthcoming 2018), https://papers.ssrn.com/sol3/papers.cfm?abstract_id=3049056.

58. BYU Law 2018 Law \& Corpus Linguistics Conference, Law \& Corpus Linguistics Project, BYU L., http://lawcorpus.byu.edu/2018-conference/ (last visited Apr. 6, 2018). 
Constitution communicate to the public? No answers to this question are provided here, but we can note some important questions that should be asked:

- What was the semantic content of the phrase "judicial power"? Was judicial power understood to encompass some version of the doctrine of stare decisis? Was the phrase "judicial power" underdeterminate with respect to precedent, allowing but not requiring the exercise of some range of binding judicial precedent?

- What was the meaning of "one Supreme Court" as contrasted with "inferior courts"? Did the characterization of the highest Court as "Supreme" (and other courts as "inferior") entail a power of vertical stare decisis, or was this power limited to what we now call "law of the case" and "claim preclusion" (res judicata)? Again, was this meaning thick (specifying the powers that accompany a "supreme" court), or thin (creating a construction zone)?

- What are the implications of the Supremacy Clause for precedent? Does the Supremacy Clause implicitly place the Constitution at the top of the hierarchy of law? Does the omission of precedent from the list of supreme law entail that judicial precedent cannot override the constitutional text?

These questions provide a sense of the inquiry that will be required at the interpretation stage. It is possible that interpretation will resolve the constitutional status of vertical and horizontal stare decisis. But there is also the possibility that the constitutional status of precedent is located in the construction zone. For example, we might conclude that the doctrine of vertical stare decisis is required by the notion of a "Supreme Court" but that the doctrine of horizontal stare decisis is underdetermined. What then?

The current state of play is that there is continued inquiry, discussion, and debate on the question as to what theory of constitutional construction should be incorporated into PMO. Two things seem clear: (1) constitutional construction must respect the Constraint Principle (consistency with the public meaning of the constitutional text in due course) and (2) the general approach to cases and issues in the construction zone must be consistent with the underlying normative justifications for 
originalism (e.g., the rule of law and democratic legitimacy). Among the possible approaches are: (1) a constitutional functions approach that emphasizes the original purposes of constitutional provisions,${ }^{59}(2)$ a default rules approach that would apply rules of deference where the constitution is not clear, ${ }^{60}$ and (3) an original methods approach that would look to original methods for resolving cases of constitutional underdeterminacy. ${ }^{61}$

These three approaches (and others) might diverge on important issues. For example, a default rules approach might give the Supreme Court discretion in the absence of a statute that codifies the doctrine of judicial precedent. The constitutional functions approach might suggest that the doctrine of stare decisis must be subordinate to the central function of the constitutional text (to govern those who govern us) and hence that nonoriginalist precedents and precedents that undermine the original functions of particular constitutional provisions are not entitled to any substantial weight in the Supreme Court. The original methods approach would require a careful investigation of the methods of constitutional construction in the 1780s; it might be that the doctrines of horizontal and vertical stare decisis as they existed at that time would be considered original methods themselves.

\section{CONCLUSION: ORIGINALISM AND PRECEDENT, AGAIN!}

The central aim of this article is to issue a call to action, urging constitutional scholars to return to the problem of precedent for originalism in a rigorous way that takes into account recent developments in constitutional theory. The focus here has been on PMO, but similar points could be made from the perspectives of intentionalism, original methods originalism, and original law originalism. Despite all the spilled ink, much work remains to be done.

59. See Barnett \& Bernick, supra note 57

60. For elaboration, see Solum, Constitutional Construction, supra note 4, at 511-23. For Lawson, see Gary Lawson, Dead Document Walking, 92 B.U. L. REV. 1225, 1233-34 (2012). For Paulsen, see Michael Stokes Paulsen, Does the Constitution Prescribe Rules for Its Own Interpretation?, 103 Nw. U. L. REV. 857 (2009). Lawson and Paulsen enunciate different sets of default rules and they believe the default rules can be gleaned from constitutional interpretation-and hence that they eliminate constitutional underdeterminacy: these issues are discussed in my Constitutional Construction.

61. McGinnis \& Rappaport, The Good Constitution, supra note 9. 